\title{
New Approach to Longwall Gate Support
}

\section{Maleki Hamid*}

Department of Mining Engineering, Colorado School of Mines, USA

Submission: August 07, 2019; Published: September 25, 2019

*Corresponding author: Maleki Hamid, Department of Mining Engineering, Colorado School of Mines, USA

\begin{abstract}
Present gate support systems are typically only passive in design, and in less than ideal ground conditions, often result in loss of travelway integrity and longwall productivity as the front abutment passes. Notably, "Mines in the western United States the amount of convergence measured in the mine entry will vary depending on how much load resistance is provided by the support system the lowest required support capacity would be one that is developed just before this critical roof deformation occurs where failure of the immediate roof is fast approaching. However, designing to this lower limit of support capacity leaves no margin of error if load conditions worsen have had limited choices for standing support [1]."
\end{abstract}

Keywords : Supported roof; Productivity; Control costs; Longwall access gates; Tail gate; Stage loader

\section{Introduction}

Providing specially designed high capacity active supports that advance with the face will provide added safety, added productivity, and lower roof control costs [2]. Workers will be able to travel from kitchen to unloaded escapeways under actively supported roof (Figure 1). Front abutments extend from a few feet to more than two hundreds of feet into the gates ahead of the longwall face. The extent of the front abutment varies due to the depth of overburden, strength of the coal, and types of overburden and the propensity to "ride" ahead of the face (Figure 2).

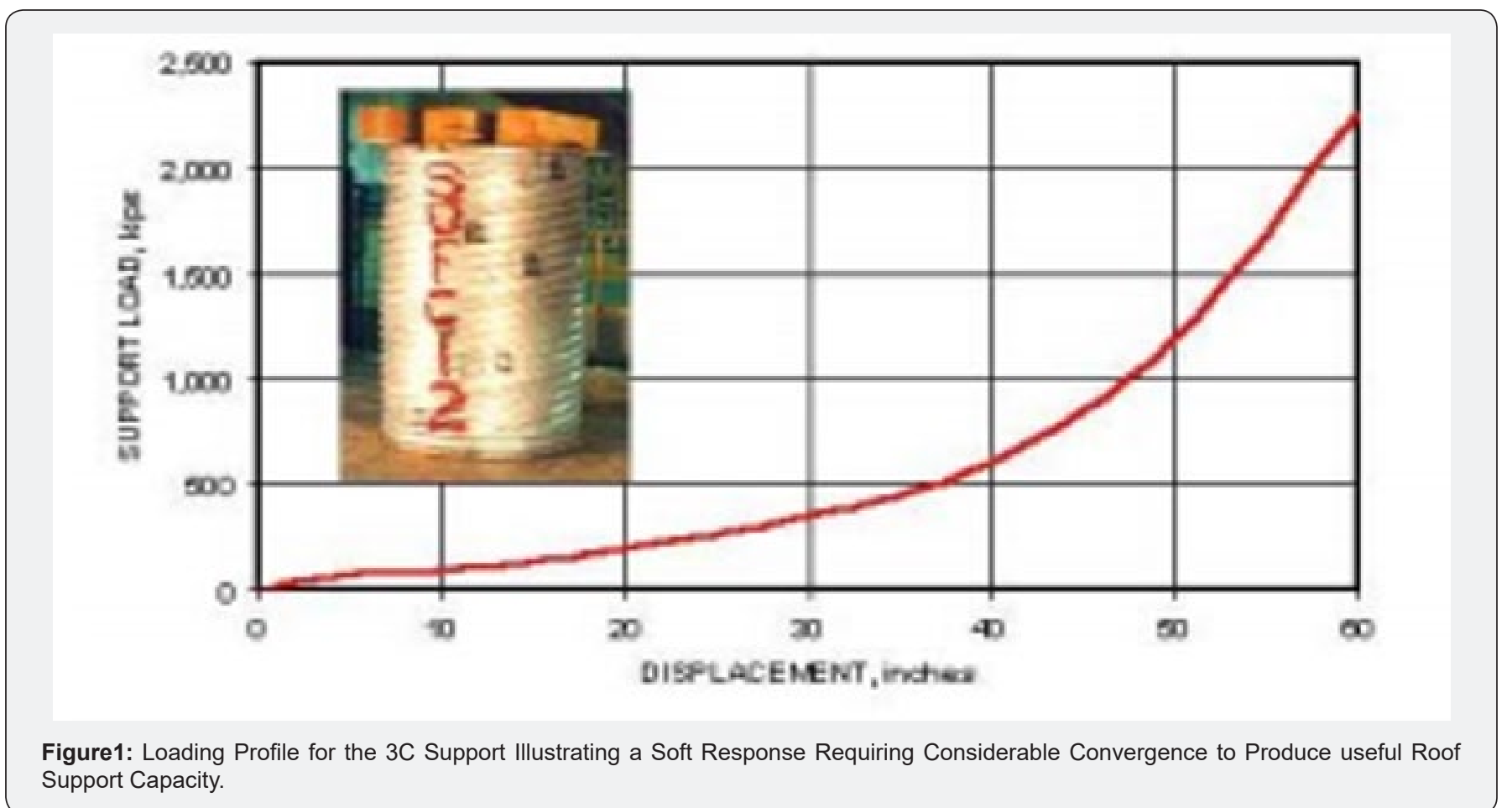




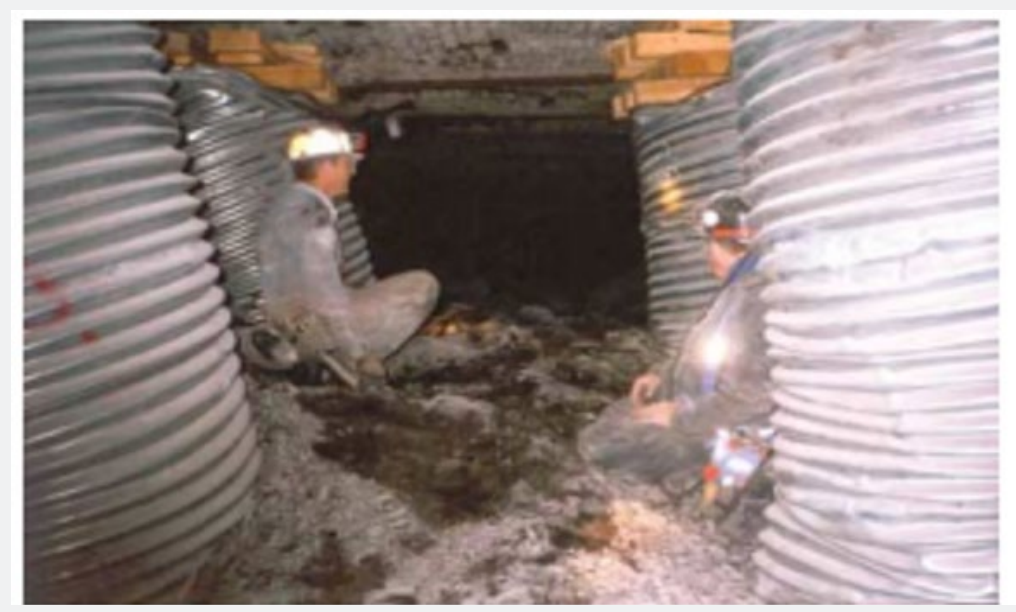

Figure2: Large Amount of Floor Heaver shown out by the Longwall Face caused Compression of the Support which Allowed it to Develop Sufficient Load Carrying Capacity for Roof Support in this Installation.

\section{Longwall Access Gates}

Abutment - In coal mining,

a. The weight of the rocks above a narrow roadway is transferred to the solid coal along the sides, which act as abutments of the arch of strata spanning the roadway

b. The weight of the rocks over a longwall face is transferred to the front abutment, that is, the solid coal ahead of the face and the back abutment, that is, the settled packs behind the face.

Although ground pressures ride out ahead of the longwall face (the front abutment), the critical longwall access gates immediately out by from (ahead of) the longwall face historically utilize only passive roof support (roof bolts, cable bolts etc.) combined at times with costly tensioned cable bolts and/or hand-set props that provide some very limited ground control capacity, that can lead to rib failures requiring additional sup port [3]. These limited support systems in the gates unfortunately too often lead to entry roof, floor, and rib failures. These failures all too often restrict head gate and tail gate travel for personnel, equipment, and airflow that results in loss of productivity. Also, the failures can result in the temporary loss or near loss of the tailgate escape way and the full airflow path.

The significant advances made in longwall face support capacities, now needs to be extended into the gates with new techniques and specialized equipment. The newly designed equipment needs to provide:

a) Active: roof, floor, and rib support by applying hydraulic or significant mechanical support prior to the arrival of the front abutment in the gate entry. This will make it possible for longwall workers to travel into the face gates completely shielded from the high stresses that form close to the longwall face. b) Significant: support pressures are needed to provide load bearing capabilities measured in the 100's of tons and like those presently in use along the longwall face.

c) Self-Advancing: capability to mesh with the self-advancing longwall supports providing for full automation of the longwall system.

d) Integrated: into longwall system to provide added gate passageway safety and incorporating the stage loader.

e) Automation: Automation of the gate support systems are essential for eventual full longwall face automation.

\section{Potential Cost Savings}

Operating cost savings can be realized in both roof control costs and productivity increases. Presently, longwall mines install extensive additional roof support in the tailgate entries and to a lesser extent in the headgate (such as added length roof bolts, cable bolts, etc). This additional, primarily passive, support is installed as the previous longwall panel is extracted and for the full length of the tailgate and headgate, at a high sunk cost for materials and labor. However, these added support systems are not fully utilized until the front abutment arrives and represent a sunk cash flow investment. Providing active and substantial supports in these entries that advance with the longwall face should make it possible to greatly reduce the need for the current added passive support systems. Also, the passive support systems in the beltway and tailgate travel way often are insufficient or less than fully effective. The lack of effective support leads to congested travel ways and slowing or stopping of production at the longwall face to clear equipment or for efficient personnel travel. Further, automation of this new advancing gate support system will provide for added safety, decreased labor costs, and decreased supply costs, with a high probability of more than offsetting the capital costs involved. Automation of the gate support systems are essential for eventual full long- 
wall face automation. These new longwall gate support concepts are addressed in: Patent US7331735B2: "Apparatus, system, and method for supporting a gate entry underground full extraction mining". Figure 3 from the patent shows the general location for the active gate support system, labeled 140. Provisional Application (filed 2018): "This disclosure relates to full extraction underground mining and more particularly relates to automated support of gate entries during longwall mining operations."

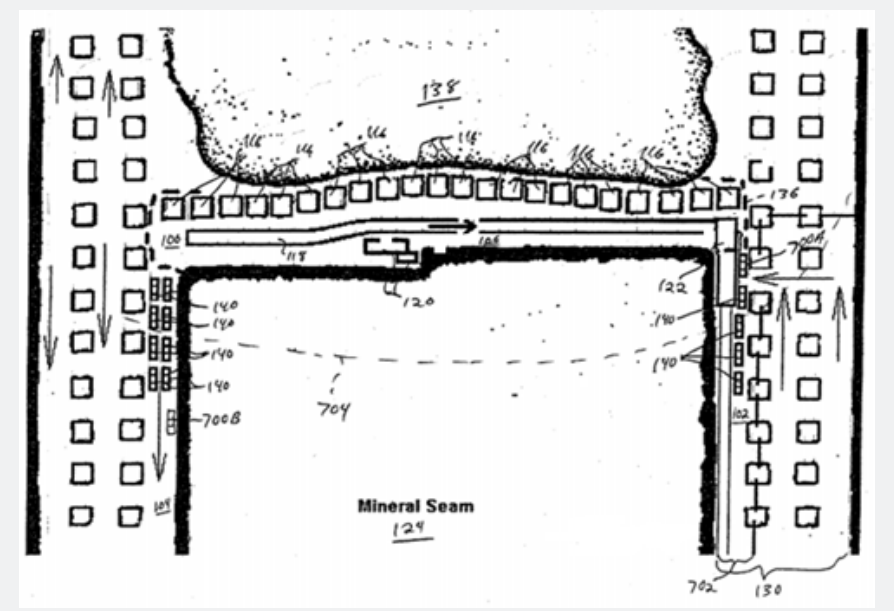

Figure 3: The General Location for the Active Gate Support System, labeled 140.

\section{References}

1. The Technology for Roof Support has Improved but Optimization is Still Not There Thomas M Barczak National Institute for Occupational Safety and Health Pittsburgh Research Laboratory Pittsburgh, PA Longwall USA pp. 112-113.
2. Barczak TM, Tadolini SC (2006) Standing support alternatives in western United States longwalls. Mining Engineering 58(2): 49.

3. Jones TH, Dubbert J (2016) Standing support and rolled mesh for safe and efficient tailgate rib control. Mining Engineering 68(1): 33-39.

Your next submission with Juniper Publishers will reach you the below assets

- Quality Editorial service

- Swift Peer Review

- Reprints availability

- E-prints Service

- Manuscript Podcast for convenient understanding

- Global attainment for your research

- Manuscript accessibility in different formats ( Pdf, E-pub, Full Text, Audio)

- Unceasing customer service

Track the below URL for one-step submission https://juniperpublishers.com/online-submission.php 